\title{
Human muscular fetal cells: a potential cell source for muscular therapies
}

\author{
Nathalie Hirt-Burri - Anthony S. de Buys Roessingh • Corinne Scaletta • \\ Stefan Gerber · Dominique P. Pioletti - Lee Ann Applegate · Judith Hohlfeld
}

Published online: 26 October 2007

(C) Springer-Verlag 2007

\begin{abstract}
Myoblast transfer therapy has been extensively studied for a wide range of clinical applications, such as tissue engineering for muscular loss, cardiac surgery or Duchenne Muscular Dystrophy treatment. However, this approach has been hindered by numerous limitations, including early myoblast death after injection and specific immune response after transplantation with allogenic cells. Different cell sources have been analyzed to overcome some of these limitations. The object of our study was to investigate the growth potential, characterization and integration in vivo of human primary fetal skeletal muscle cells. These data together show the potential for the creation of a cell bank to be used as a cell source for muscle cell therapy and tissue engineering. For this purpose, we developed primary muscular cell cultures from biopsies of human male thigh muscle from a 16-week-old
\end{abstract}

N. Hirt-Burri and A. S. de Buys Roessingh contributed equally to this work.

N. Hirt-Burri $(\bowtie)$ · A. S. de Buys Roessingh · J. Hohlfeld

Pediatric Surgery Laboratory, University Hospital Lausanne, CHUV, CI/02/60, 1011 Lausanne, Switzerland

e-mail: Nathalie.Burri@chuv.ch

C. Scaletta $\cdot$ L. A. Applegate

Orthopedic Cell Therapy Unit, University Hospital Lausanne,

Lausanne, Switzerland

S. Gerber

Department of Obstetrics, University Hospital Lausanne,

Lausanne, Switzerland

C. Scaletta - D. P. Pioletti - L. A. Applegate

Laboratoire de Biomécanique en Orthopédie (EPFL-HORS), Institut de Biomécanique Translationnelle, Ecole Polytechnique

Fédérale de Lausanne, Lausanne, Switzerland fetus and from donors of 13 and 30 years old. We show that fetal myogenic cells can be successfully isolated and expanded in vitro from human fetal muscle biopsies, and that fetal cells have higher growth capacities when compared to young and adult cells. We confirm lineage specificity by comparing fetal muscle cells to fetal skin and bone cells in vitro by immunohistochemistry with desmin and 5.1H11 antibodies. For the feasibility of the cell bank, we ensured that fetal muscle cells retained intrinsic characteristics after 5 years cryopreservation. Finally, human fetal muscle cells marked with PKH26 were injected in normal C57BL/6 mice and were found to be present up to 4 days. In conclusion we estimate that a human fetal skeletal muscle cell bank can be created for potential muscle cell therapy and tissue engineering.

Keywords Cell therapy - Tissue engineering ·

Fetal cells $\cdot$ Muscle $\cdot$ Myoblast transplantation

\section{Introduction}

Over the past years, myoblast transfer therapy or skeletal myoblast transplantation has emerged as a potential therapeutic option for the treatment of muscular dystrophies [1-4], the repair of infarcted myocardium [5] and the regeneration of muscular loss [6]. The capacity of skeletal myoblasts to restore dystrophin expression in dystrophic recipients $[7,8]$ or engraft into infarction scars [9] was demonstrated in several animal models, such as mice, dogs and primates [10-13]. However, the effectiveness of these techniques is hindered by numerous limitations, including minimal distribution of cells after injection [14], immune rejection [15] and poor cell survival [16-23]. A major limitation of cell transplantation 
remains death of the grafted cells. Up to $90 \%$ of these cell types have been reported to be killed over the first $48 \mathrm{~h}$ following their implantation [24, 25]. This major loss of grafted cells is likely to seriously hamper the efficacy of the procedure, as the functional benefit expected from myoblast transplantation seems closely related to the number of injected myoblasts [26]. Efforts have been made to improve cell survival, either by changing immunosuppressive or anti-inflammatory agents [27-29], changing the cell source [30] and pretreatment of cells [31] or by improving purification of specific cells populations [32-35].

Stem cells have raised the hope of scientists as they have high self-renewal capacity and can generate multiple cell lineages [36]. For muscular therapies, they have been isolated not only from muscle [37] but also from many tissues including bone marrow [38], amniotic fluid [39] and umbilical cord blood [40]. Although widely distributed, stem cells represent only a small fraction of a tissue cell population, and they require an extensive in vitro expansion technique, and cultures of stem cells are usually technically very demanding. Only Atala's group has been able to establish consistent stem cell cultures without the use of a feeder layer [41]. Nonetheless, many growth factors are still necessary to direct the cell type, and large expansion of these cells is not feasible [42]. Unlike stem cells, fetal cells are differentiated cells with high expansion and regeneration and low immunogenic properties $[43,44]$. They can be isolated from fetal tissues, which follow the embryonic stage of 9 weeks of development. Fetal cells are mature, fully differentiated cells and capable of proliferating rapidly $[45,46]$ and have a higher resistance to oxydatif stress than adult cells [47]. Moreover, fetal tissue is not easily rejected by the recipient due to the low levels of histocompatibility antigens [43, 48, 49]. Fetal tissue is used for transplantation in adults to treat Parkinson's [50] or Huntington's disease [51] with fetal neurons, and human fetal pancreas has been transplanted in diabetic patients [52]. Applications of fetal cell therapy are also of interest in the orthopedic area, where human fetal bone cells were shown to have high proliferation and differentiation ability and could be used as a source of cells for bone tissue-engineering [53, 54]. Recently, biological bandages composed of fetal skin fibroblasts improve skin regeneration in second- and thirddegree burned children [45, 47]. A highly consistent fetal skin cell bank was created with which it was possible to produce more than 270 million skin constructs for therapeutic use from one organ donation $[47,55]$.

In this study, we estimate the feasibility for the creation of a human fetal skeletal muscle cell bank for potential muscle cell therapy applications. We show that myogenic cells can be successfully isolated and expanded in vitro from human fetal and adult muscle biopsies and that fetal cells have higher growth capacities. Human fetal skeletal muscle cells were implanted in immunocompetent C57BL/6 mice to assess cellular survival at 1 and 4 days after injection.

\section{Materials and methods}

Muscle biopsies and cell culture

Two human fetal skeletal muscle biopsies (15 and 16 weeks), one fetal skin biopsy (14 weeks) and one fetal bone biopsy (16 weeks) were obtained after pregnancy termination with written, informed consent and approval of the local Medical School Ethics Committee in the Department of Obstetrics in Lausanne University Hospital. Skeletal muscle samples from adult donors (13 and 30 years) were obtained during surgery of the thighs, also with written, informed consent and approval from the Medical School Ethics Committee. All the muscle samples, measuring $1 \mathrm{~cm}^{3}$, were obtained from thigh muscle for each patient. Primary cultures of fetal skin cells and fetal bone cells were developed as described previously $[45,47,56]$.

Primary muscle cultures were established for all samples. Each biopsy was rinsed in phosphate-buffered saline (PBS $1 \times)$ containing penicillin $(100 \mathrm{U} / \mathrm{ml})$ and streptomycin (100 U/ml) (Gibco BRL, Life Technologies, Grand Island, NY, USA). Then, muscle tissues were digested in $2.3 \mathrm{mg} / \mathrm{ml}$ type I collagenase (Gibco BRL) in Dulbecco's Modified Eagles Medium (DMEM, Gibco BRL) at $37^{\circ} \mathrm{C}$ for $1 \mathrm{~h}$. After digestion, muscle fibers were dissociated with a $1 \mathrm{ml}$ pipette, and transferred into a fresh medium consisting of DMEM containing 10\% fetal bovine serum (FBS, Gibco BRL). Cells were grown at $37^{\circ} \mathrm{C}$ in a humidified atmosphere with $90 \%$ air $/ 5 \% \mathrm{CO}_{2}$. Once the cells reached $80 \%$ confluency, they were trypsinized (EDTA and trypsin solution, Gibco BRL) and expanded in T80 Falcon tissue culture flasks. When expanded cells reached $80 \%$ confluency, they were trypsinized and centrifuged at $1,000 \mathrm{~g}$ for $15 \mathrm{~min}$ and resuspended in a freezing solution of DMEM $(5 \mathrm{ml})+$ FCS $(4 \mathrm{ml})+\operatorname{DMSO}(1 \mathrm{ml}$, Fluka) and frozen in $1 \mathrm{ml}$ aliquots (1-2 million cells) at $-80^{\circ} \mathrm{C}$ in Nalgene ${ }^{\mathrm{TM}}$ Cryo $1^{\circ} \mathrm{C}$ Freezing Container's (Nalgene) to achieve a $-1{ }^{\circ} \mathrm{C} / \mathrm{min}$ rate of cooling and freezing curve. After $24 \mathrm{~h}$, cells were transferred to liquid nitrogen for longer storage. A second round of expansion was performed and cells stored at the same conditions at 
passage 2. Cells were thawed for different experiments and used between passages 2 to 4 .

Growth curves

Fetal (16 weeks), young (13 years) and old (30 years) muscle cells were thawed, expanded and seeded at $2.5 \times 10^{3}$ cell in 6 well culture dishes $(4 \mathrm{~cm}$ diameter $)$. At each time point, cells were detached from culture dishes with $1 \mathrm{ml}$ of trypsin/EDTA (Gibco BRL), the reaction was stopped by the addition of culture medium; cell suspension was centrifuged at $1,000 \mathrm{~g}$ for $5 \mathrm{~min}$ and counted in triplicate.

Fetal muscle cells (15 weeks), fetal bone cells (16 weeks) and fetal skin fibroblast cells (14 weeks) were thawed expanded and seeded at $1 \times 10^{4}$ cell in $6 \mathrm{~cm}$ diameter dishes in triplicate. At each time point, cells were detached from culture dishes with $1 \mathrm{ml}$ of trypsin/EDTA (Gibco BRL), and the reaction was stopped by the addition of culture medium. Cell suspension was centrifuged at $1,000 \mathrm{~g}$ for $5 \mathrm{~min}$, and cells were counted in triplicate.

Immunohistochemistry

Cells were grown on round glass slides $(1 \mathrm{~cm}$ in diameter) and when they reached 80-90\% confluency they were fixed with acetone for $10 \mathrm{~min}$ at room temperature. Slides were washed in PBS $1 \times$ and incubated with normal goat serum (NGS, DAKO, Denmark) for $30 \mathrm{~min}$ at room temperature to block non-specific binding sites. Tissue sections were then incubated for $30 \mathrm{~min}$ at room temperature with an anti-desmin antibody (clone D33, DAKO, Denmark, 1:100) or the $5.1 \mathrm{H} 11$ monoclonal antibody, obtained from the Developmental Studies Hybridoma Bank $(1: 1,000$, the University of Iowa, Iowa City, USA). This monoclonal antibody $5.1 \mathrm{H} 11$ has been shown to specifically recognize a surface antigen (Neural Cell Adhesion Molecule, NCAM) on human myogenic
Fig. 1 Top. Cell growth of human skeletal muscle primary cells as a function of time for fetal, young and old starting with 260 cells $/ \mathrm{cm}^{2}$ for each sample. Each data point is represented by the average cell number from three culture plates. Bottom 5.1H11 and desmin immunohistochemical staining of fetal, young and adult skeletal muscle primary cell culture. $\times 50$ magnification

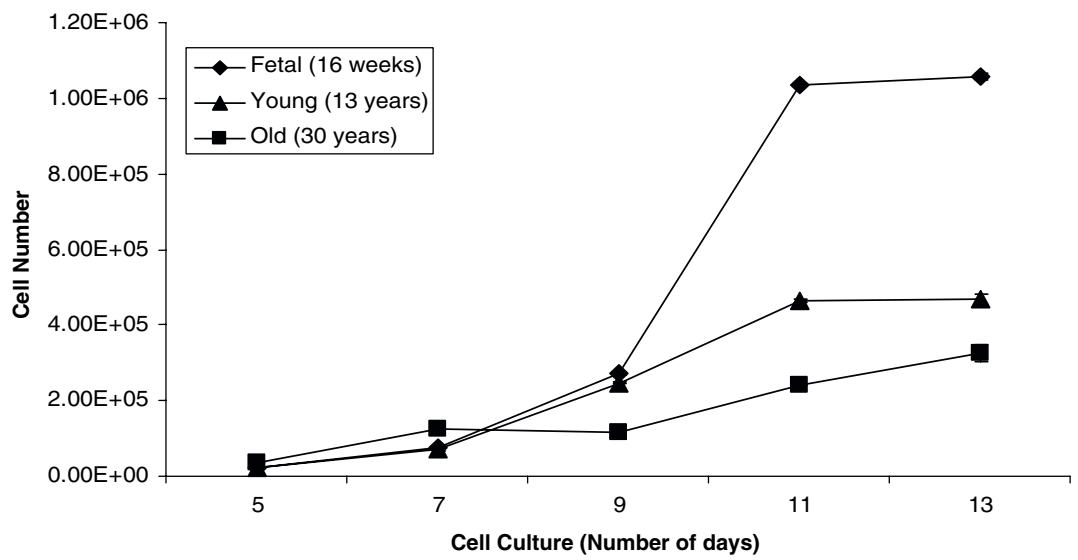

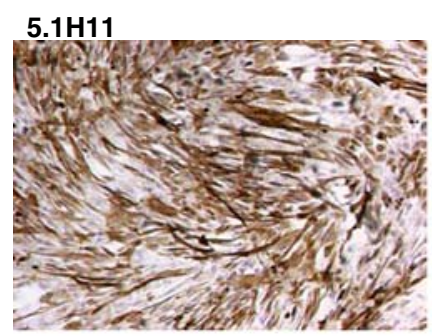

Fetal 16 weeks

Desmin

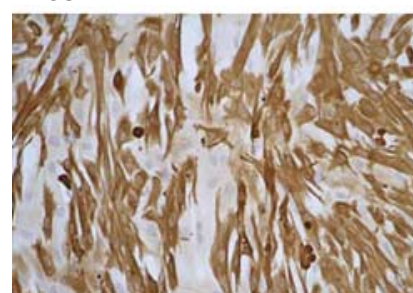

Fetal 16 weeks

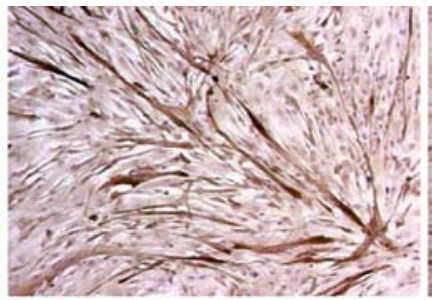

Young 13 years

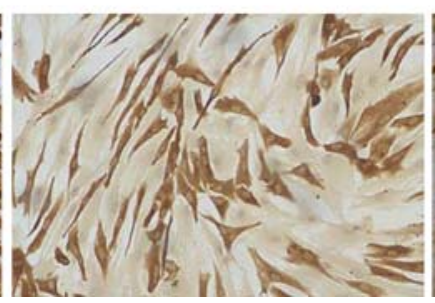

Young 13 years

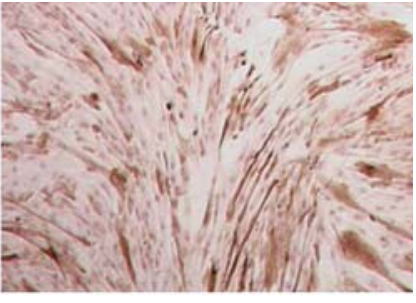

Adult $\mathbf{3 0}$ years

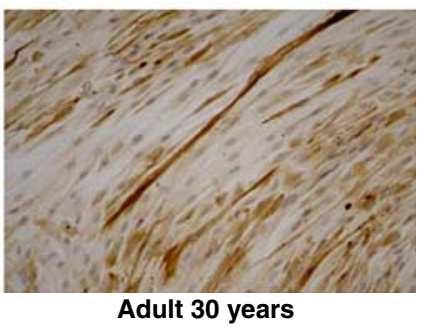


Fig. 2 Top. Cell growth of skeletal muscle, skin and bone human fetal primary cells as a function of time with 260 cells/ $\mathrm{cm}^{2}$ for each sample. Each data point is represented by the average cell number from three culture plates. Bottom 5.1H11 and desmin

immunohistochemical staining of fetal skeletal muscle, skin and bone primary cell culture. $\times 50$ magnification

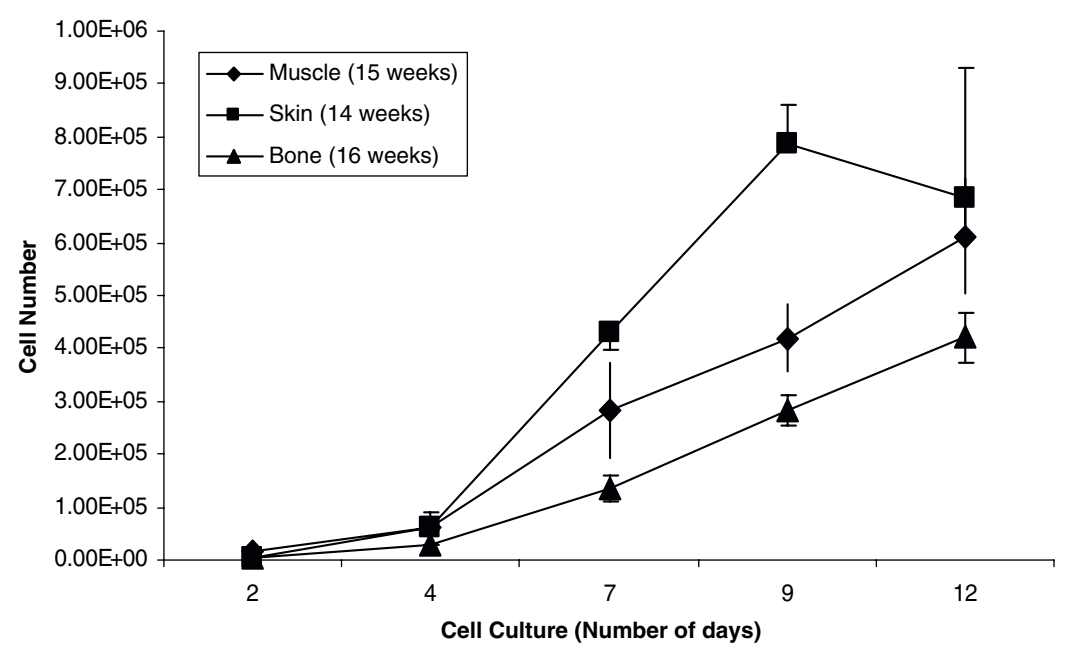

5.1H11

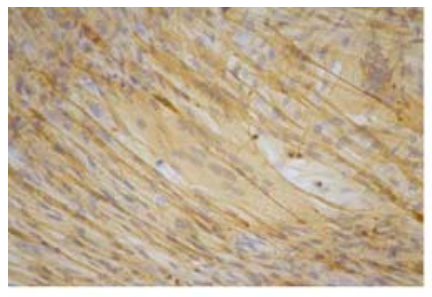

Muscle

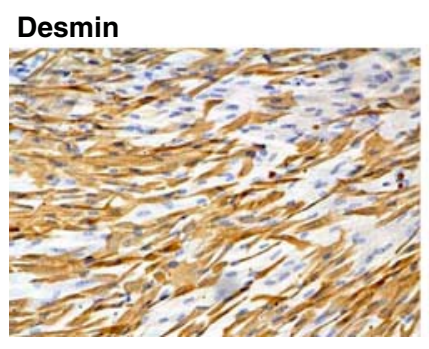

Muscle

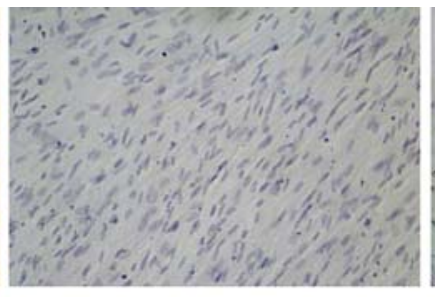

Skin

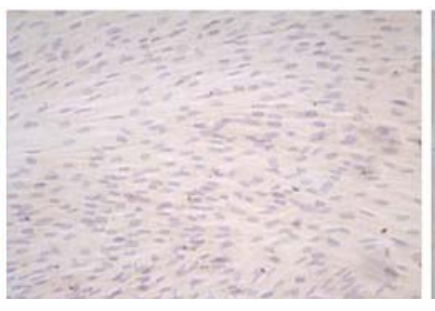

Skin

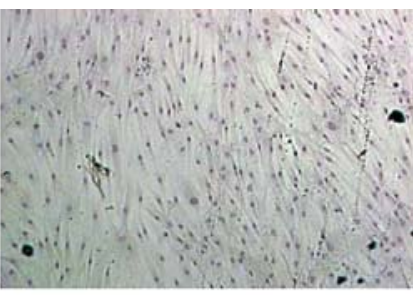

Bone

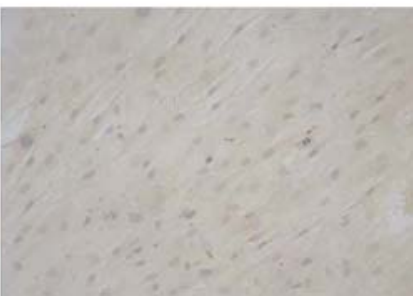

Bone cells [57]. Following washes in PBS 1×, sections were incubated with biotinylated secondary anti-mouse antibody (Vector, Burlingame, CA, USA; 1:200) for $30 \mathrm{~min}$ at room temperature. Samples were then incubated for $30 \mathrm{~min}$ at room temperature in Vectastain $\mathrm{ABC}^{\circledR}$ (Vector, Burlingame, CA, USA), a solution of a complex of avidin/biotin peroxydase, as described by the company. Following this incubation, tissue sections were washed

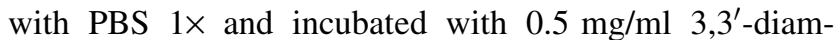
inobenzidine with $0.32 \mu \mathrm{l} 30 \% \mathrm{H}_{2} \mathrm{O}_{2}$ added just before an incubation of 1-2 min. All samples were treated simultaneously. The samples were then washed for 5 min under running water, counterstained with Papanicolaou (Harris' hematoxylin solution), dehydrated and mounted with Merckoglas ${ }^{\circledR}$ (Merck). Sections stained for each antibody were analyzed with a Leica DFC280 videoimaging system.
Cell labeling for animal experimentation

Fetal muscle cells (16 weeks) were thawed and expanded in cell culture. Cell viability was monitored, and desmin immunohistochemistry was performed to ensure the quality of the cells. Fetal muscle cells were labeled with the PKH26 Red Fluorescent Cell Linker Kit (Sigma-Chemicals, St. Louis, MO, USA) as follows: $2 \times 10^{6}$ were washed once in serum-free medium (DMEM) and suspended in $250 \mu \mathrm{l}$ of Diluent solution $\mathrm{C}$ (included in the PKH26 labeling kit). A volume of $250 \mu \mathrm{l}$ of PKH26 at $2 \times 10^{-3} \mathrm{M}$ in Diluent $\mathrm{C}$ was added, mixed, and cells were incubated for $5 \mathrm{~min}$ at room temperature. The labeling reaction was terminated by adding $500 \mu \mathrm{l}$ of FBS. The cell suspension was centrifuged, washed three times with DMEM, $10 \%$ FBS. The concentration of fetal muscle cell suspension labeled with PKH26 was adjusted to 
$1 \times 10^{6}$ cells $/ \mathrm{ml}$ with PBS ready to be used for injection into recipient mice.

\section{Cell survival in PBS}

Cell viability of PKH26 marked fetal cells was assessed by trypan blue exclusion (Sigma Chemicals). After PKH26 cell labeling, cells were left at room temperature, and trypan blue cell exclusion was performed every $30 \mathrm{~min}$ until $4 \mathrm{~h}$ and after $24 \mathrm{~h}$. At each time point, a freshly prepared solution of $10 \mu \mathrm{l}$ trypan blue $(0.05 \%)$ in distilled water was mixed with $10 \mu \mathrm{l}$ of cellular suspension for $5 \mathrm{~min}$, and the cells were then counted with the aid of a hemacytometer.

In vivo assessment of fetal myoblast cell injection

The animal study was approved by the local Ethics Committee of the Lausanne University Hospital under protocol \#1585. Twelve-week-old male C57BL/6 mice were obtained from Iffa Credo and were housed locally for at least 1 week before the experimentation began. Eleven mice were anesthetized $(5 \mu \mathrm{l} / \mathrm{mg}$ mice of a mix containing $500 \mu \mathrm{l}$ Rampun, $2 \mathrm{ml}$, Ketalar and $2.5 \mathrm{ml}$ PBS). Left and right tibialis anterior muscles (TA) were punched with a 21-gauge needle six times in a circular fashion within $0.5 \mathrm{~cm}$ diameter to create an injury. The center of the left injured TA muscle was injected with $5 \times 10^{4} \mathrm{PKH} 26$ marked male fetal muscular cells in PBS with a Hamilton syringe (Bonaduz, CH, USA). The center of the right injured TA muscle was injected with vehicle (PBS) as an internal control.

Five mice were killed 24 hours after the intervention and 6 mice 4 days later. TA muscles were frozen in liquid nitrogen-cooled isopentane and cryostat sectioned. Frozen sections $(6-10 \mu \mathrm{m})$ were DAPI stained to visualize nuclei and were examined for the presence of PKH26 red fluorochrome with an Olympus BX-40 microscope fitted with appropriate filters. Other frozen sections were stained with hematoxylin and eosin (H\&E).

Nucleic acid extraction and reverse transcription

Total RNA was extracted from primary cell lines and from twenty $25 \mu \mathrm{m}$ sections of frozen mice TA muscles tissue using the NucleoSpin, RNA II kit (NucleoSpin, RNA II, Marchery-Nagel, Düren, Germany) as described by the manufacturer. RNA integrity was assessed on a $1 \%$ agarose gel.
Two micrograms of total RNA were reverse transcribed using $50 \mathrm{U}$ of StrataScript reverse transcriptase enzyme (Stratagene, San Diego, CA, USA) in a volume of $50 \mu \mathrm{l}$ containing first strand buffer (Stratagene), $3 \mu \mathrm{l}$ of random primers $(100 \mathrm{ng} / \mu \mathrm{l}), 40 \mathrm{U}$ of RNasin (Promega, Madison, WI, USA) and $2 \mu \mathrm{l}$ of dNTP mix $100 \mathrm{mM}$ (Promega), as described by the manufacturer. The thermocycler Biometra T-1 (Biomedizinische Analytik $\mathrm{GmbH}$, Göttingen, Germany) was programmed as follows: $65^{\circ} \mathrm{C}$ for $10 \mathrm{~min}$, $37^{\circ} \mathrm{C}$ for $60 \mathrm{~min}$ and $90^{\circ} \mathrm{C}$ for $5 \mathrm{~min}$.

Reverse transcriptase polymerase chain reaction (RT-PCR)

Desmin cDNA fragment of $519 \mathrm{bp}$, actin cDNA fragment of $739 \mathrm{bp}$ and $18 \mathrm{~S}$ cDNA fragment of $486 \mathrm{pb}$ were amplified by RT-PCR using the primer sets as follows, respectively: (Desmin) forward 5'-CCTACTCTGCCCTCA

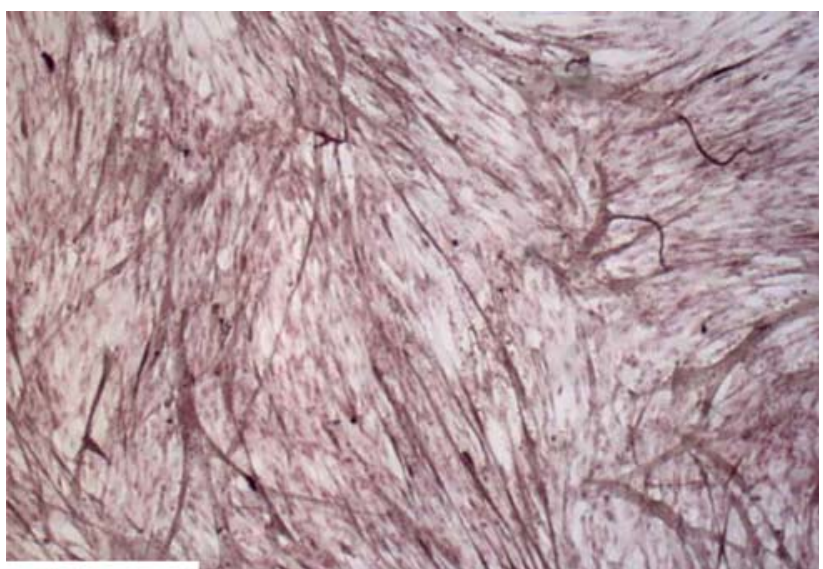

\section{$5.1 \mathrm{H} 11$}

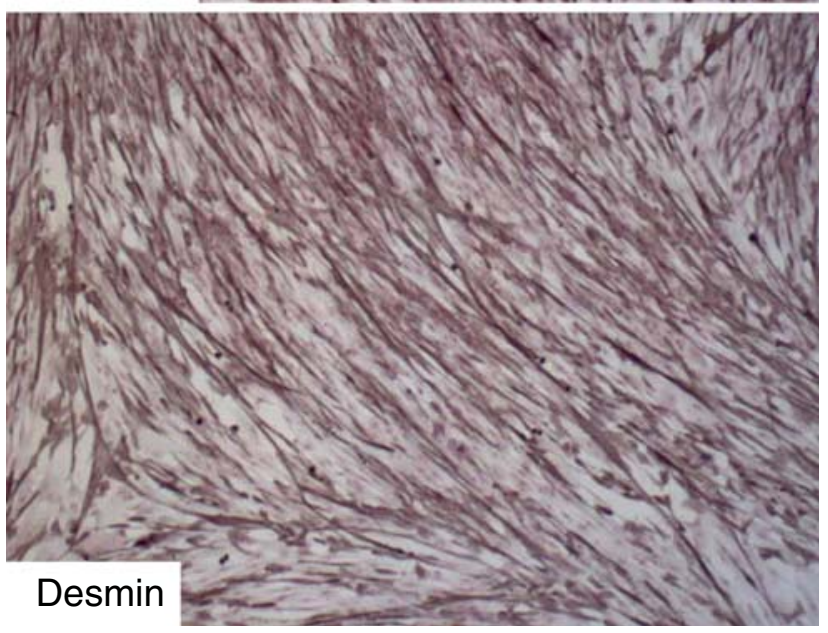

Fig. $35.1 \mathrm{H} 11$ and desmin immunohistochemical staining of fetal skeletal muscle primary cell culture after 5 years of cryopreservation. $\times 50$ magnification 


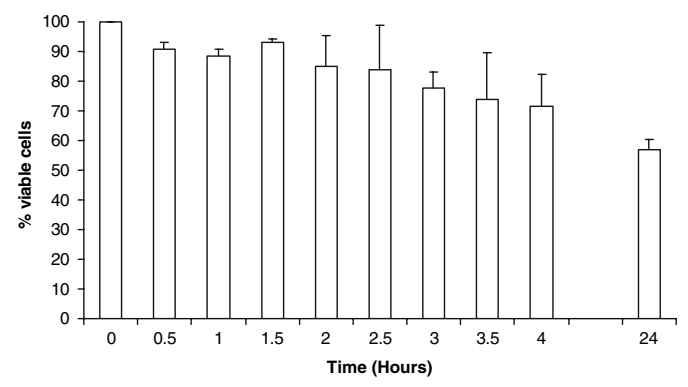

Fig. 4 Cell viability of cells stored $24 \mathrm{~h}$ at room temperature in PBS. Measurements were performed in triplicate with associated SD of the mean

ACTTC- $3^{\prime}$ and reverse 5'-AGTATCCCAACACCCTGC TC-3', (Actin) forward 5'-GTTGCTATCCAGGCTGTG-3' and reverse $5^{\prime}$-CATAGTCCGCCTAGAAGC-3', (18S) forward $5^{\prime}$-TTAAGCCATGCATGTCTAAGTAC-3' and reverse $5^{\prime}$ - TGTTATTTTTCGTCACTACCTCC- $3^{\prime}$ with a Biometra T-1 thermocycler (Biomedizinische Analytik $\mathrm{GmbH}$, Göttingen, Germany) . After denaturation at $95^{\circ} \mathrm{C}$ for $5 \mathrm{~min}, 25$ to 35 cycles of amplification were performed as follows: $94^{\circ} \mathrm{C}$ for $45 \mathrm{~s}$, annealing temperature (Desmin: $65^{\circ} \mathrm{C}$; Actin: $60^{\circ} \mathrm{C} ; 18 \mathrm{~S}: 55^{\circ} \mathrm{C}$ ) for $30 \mathrm{~s}, 72^{\circ} \mathrm{C}$ for $30 \mathrm{~s}$, and finally an elongation of $72^{\circ} \mathrm{C}$ for 15 min. PCR products were electrophoresed together on a $2 \%$ agarose gel.

\section{Results}

Cell growth and expression of muscle markers in fetal muscle cells

The growth of fetal muscle cells has been shown to be much greater than that of cells from adult donors. Although growth of fetal cells can be observed already in the initial days after muscle fibers have been placed in culture dishes, growth of adult muscle cells treated under the same conditions usually starts only after 10-12 days. Once cultures are established, fetal cells continue to grow at a much faster rate than cells from adults (Fig. 1). The analysis of cell number as a function of days in culture when starting with a low number of cells $\left(260 \mathrm{cell} / \mathrm{cm}^{2}\right)$ shows a sharp difference after 11 days of culture. This difference in the growth rate is related to the age of the donor.

In a simple culture medium, fetal muscle cells express a higher density of muscle markers, such as desmin and $5.1 \mathrm{H} 11$, than that of young and adult cells cultivated under the same conditions (Fig. 1).

When compared with fetal skin fibroblasts used in clinics [45, 47] and bone-derived fetal cells (Fig. 2), it appears that primary fetal cultures are tissue specific. Fetal skin fibroblasts reach confluence earlier (after 9 days) than muscle and bone fetal cells. Each primary cell line has a specific growth capacity and only fetal muscle cells express muscular markers (Fig. 2).

Human skeletal muscle fetal cells cryopreservation

After 5 years of liquid nitrogen storage, primary fetal skeletal muscle cells were thawed and expanded; immunohistochemistry was performed for the 5.1H11 and desmin muscular markers. Each of the fetal cell lines showed almost the same quantity of cells expressing desmin and $5.1 \mathrm{H} 11$ as did the ones before long-term conservation (Fig. 3 compared to Figs. 1, 2). Adult cells (30 years) could not be expanded after 5 years of cryopreservation. Under the same conditions, young (13 years) cells could be thawed and expanded but there were fewer cells expressing desmin or $5.1 \mathrm{H} 11$ (data not shown).

Survival of human fetal skeletal muscle cells in PBS

A certain number of hours can elapse between the time of preparation of the cells and their implantation into hosts in animal experiments or in hospitalized patients. We monitored the death rate of cells kept at room temperature in PBS, to estimate how long one could wait before injection and still have a majority of live cells. Figure 4 shows more than $70 \%$ of fetal skeletal muscle cells still alive after $4 \mathrm{~h}$ at room temperature in PBS. After $24 \mathrm{~h}$, more than $60 \%$ of the cells were alive and with the same morphology.

In vivo assessment of fetal skeletal muscle injection

Human fetal cells marked with PKH26 were visible after $24 \mathrm{~h}$ in the five analyzed mice, and they were still clearly observed at 4 days after the injection. No PHK26 labeled cells were observed in any of the collateral TA muscles (Fig. 5).

Hematoxylin and eosin (H\&E) coloration was performed on $10 \mu \mathrm{m}$ sections slides of wounded mice TA muscles (Fig. 6). Twenty-four hours after injury, wounded sites had no more infiltrating cells at the site of human fetal cell injection. At 4 days after injection mononucleated cells (inflammatory cells and myoblasts) increased in number as expected; again there is not much inflammation in the injected site in comparison to the internal control 
injected with PBS. Regenerating fibers are observable in both (left and right) TA muscles.

RNA was extracted from 20 tissue sections of $25 \mu \mathrm{m}$ thickness with Trizol. RNA was quantified by optic density. Fluorescence analysis was performed on a slide before and after the 20 cryosections to ensure that human PKH26 marked cells were present. Amplification was accomplished for the human $\beta$-actin gene and for the mouse $18 \mathrm{~S}$ as a positive control for the RNA quality. Presence of human $\beta$-actin RNA was observed in samples 1 and 4 days after injection (Fig. 7). Presence of $\beta$-actin was only observed in the left fetal cell treated TA muscle. It was not possible to observe desmin expression by classic RT-PCR in the samples.

\section{Discussion}

Herein, we investigate the possibility to create a human primary fetal skeletal muscle cell bank that could be used as a cell source for muscle cell therapy and tissue engineering. To this purpose, we first analyzed the growth capacity of fetal muscle cells compared to adult cells by means of specific muscle markers. Then, we compared fetal muscle cells to fetal skin and bone cells in vitro under identical culture conditions to determine their lineage specificity. We ensured that fetal muscular cells kept their characteristics after long-term cryopreservation. Finally, human fetal muscle cells were injected in normal C57BL/6 mice to assess survival after up to 4 days.

The proliferation rate of primary fetal muscle cells was similar to that of fetal skin and fetal bone cells, but more rapid than young and adult muscle donor cells. Moreover, the growth rate of muscle cells was age-related as described previously by Schäfer et al. [58]. Primary fetal muscle cells showed a higher number of cells expressing desmin than did young and adult derived muscle cells. Fetal muscular cells were found to conserve their high desmin counts after long-term cryopreservation. Schäfer et al. demonstrate that when human muscle cultured cells
Fig. 5 Right Fluorescence analysis for the presence of PKH26 (red) human fetal skeletal muscular on mice left and right TA muscle cryosections. Nuclei are counterstained with Dapi (blue). At 1 day post-injection red labeled cells are found in left TA muscle $(1 d L)$ and not in the right control TA muscle ( $1 d R$ ). At 4 days after injection, red labeled cells are found in left TA muscle $(4 d L)$ and not in the right control TA muscle ( $4 d R$ ). $U$ Uninjured muscle. $\times 100$ magnification
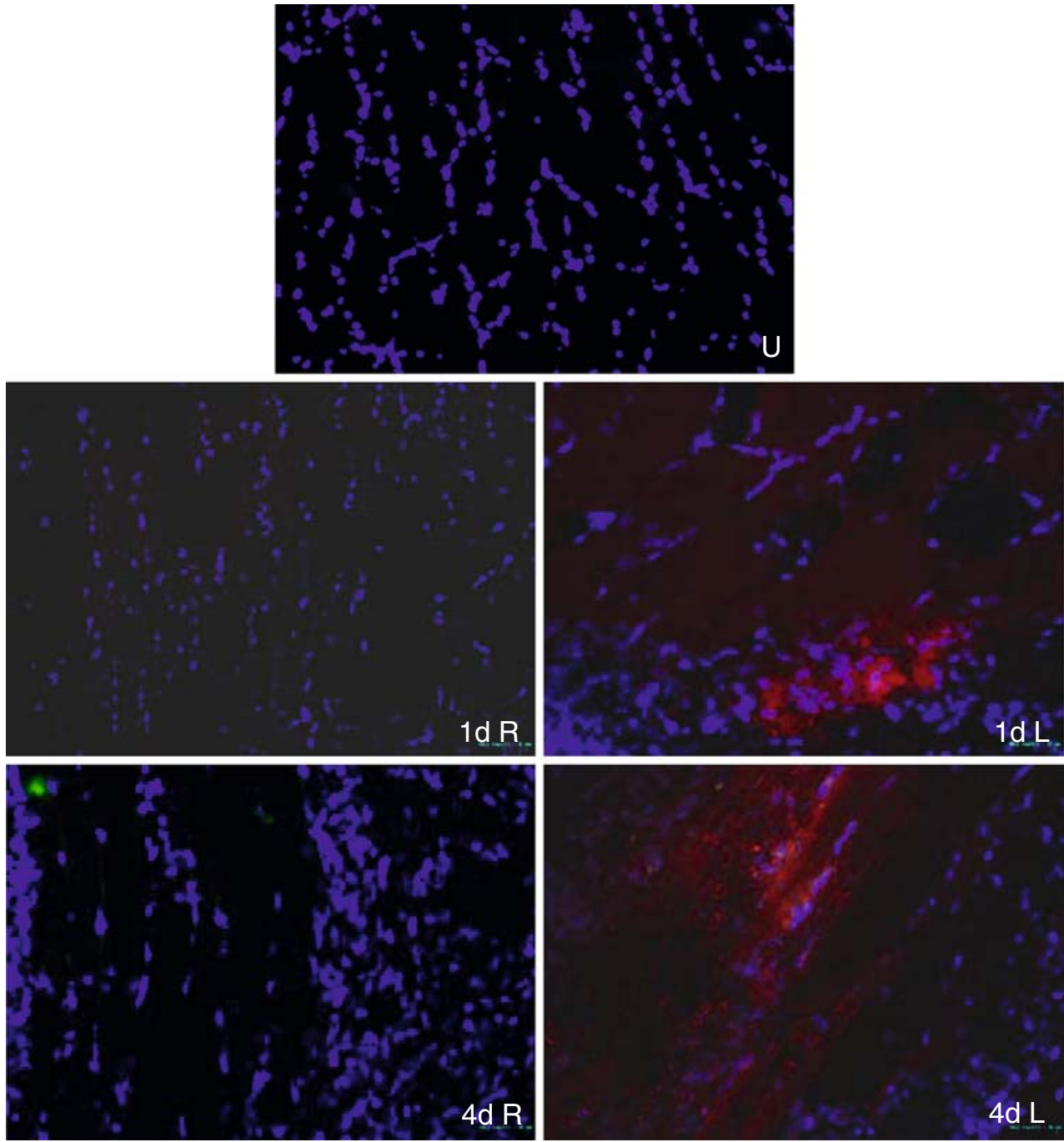


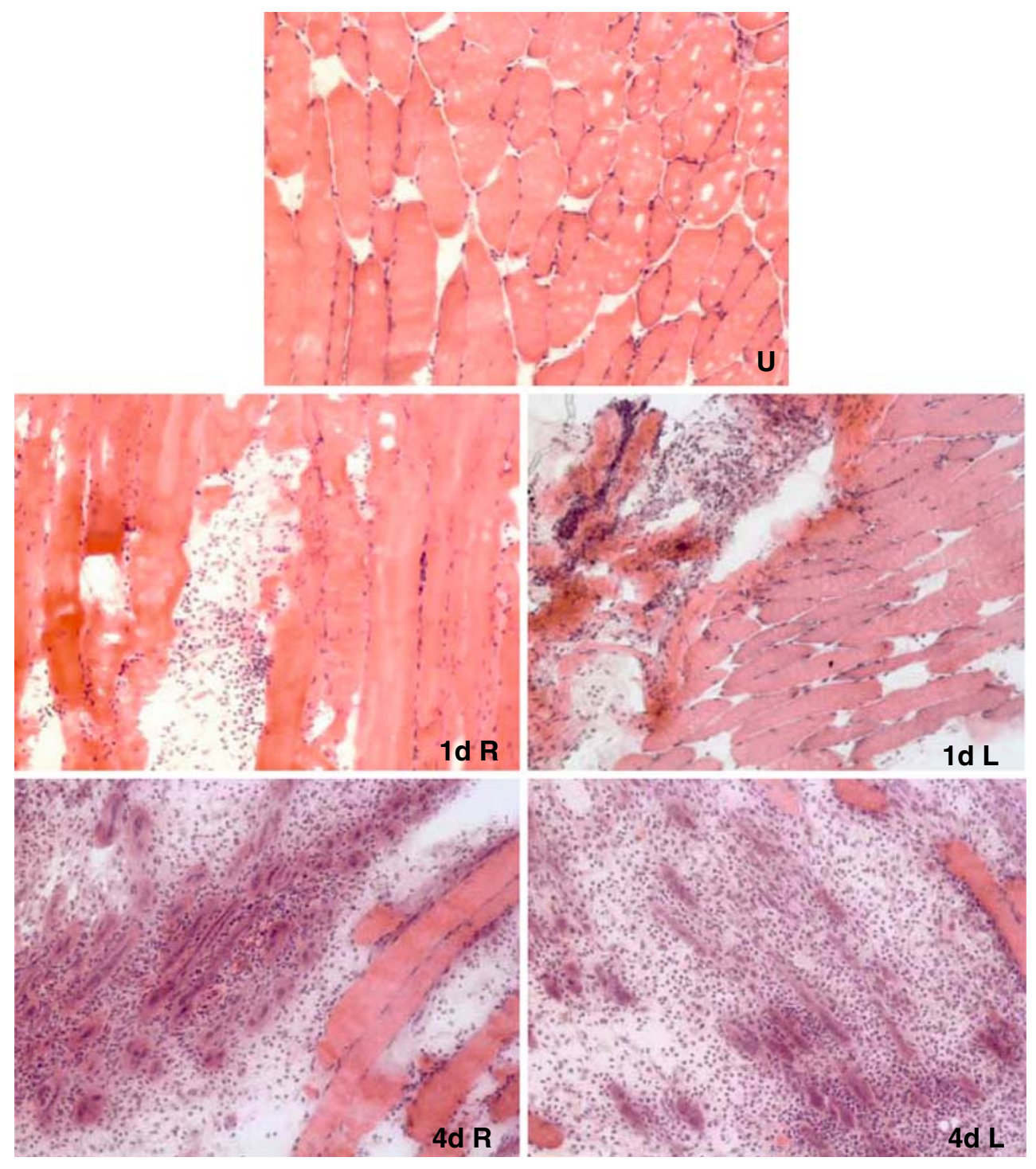

Fig. 6 Left TA muscle histology 1 and 4 days post-injection of human fetal skeletal muscle cells. Fetal muscle injected left $(L)$ and vehicle injected right $(R)$ TA muscle cryosections were H\&E stained. Uninjured muscle $(U)$ shows a typical pattern of evenly sized myofibers with peripheral nuclei. One day after injection, the needle

maintain their high desmin content or show little loss during expansion in vitro, they produce more myogenic than non-myogenic nuclei in vivo [59].

Cell delivery is an important aspect of cell therapy; several hours can elapse from the laboratory to the clinical application with fetal cells. We show that even after $24 \mathrm{~h}$ at room temperature in saline solution $60 \%$ of fetal muscle cells are still viable. After $1 \mathrm{~h}$ results are comparable with other publications which show 93-97\% viability of the cells after $1 \mathrm{~h}$ on ice [60]. The reason for the rapid death of injected myoblasts is still unclear; immunological rejection was considered but the timing of sectioned muscle is visible with little infiltrating mononuclear cells, for left and right TA muscle ( $1 d R$ and $1 d L$ ). At 4 days after injury mononucleated cells (inflammatory cells and myoblasts) increase in number, and appearance of new myotubes is observed for left and right TA muscles $(4 d R$ and $4 d L) . \times 100$ magnification

cellular death (1-48 h) combined with the fact that whole muscle grafts in mice (uncultured cells) show good survival after 1 year argues against it [61]. These data strongly suggest that myoblast isolation and culture can have adverse effects on the survival of donor cells into in vivo situation. On the other hand, Tambara et al. have recently shown that neonatal skeletal myoblasts can fully replace an infarcted myocardium when they survive in the host in large number. When $5 \times 10^{7}$ skeletal neonatal muscles cells were injected in infarcted rat hearts, a reversion of LV remodeling was observed, whereas when $5 \times 10^{5}$ skeletal muscle cells were injected remodeling 

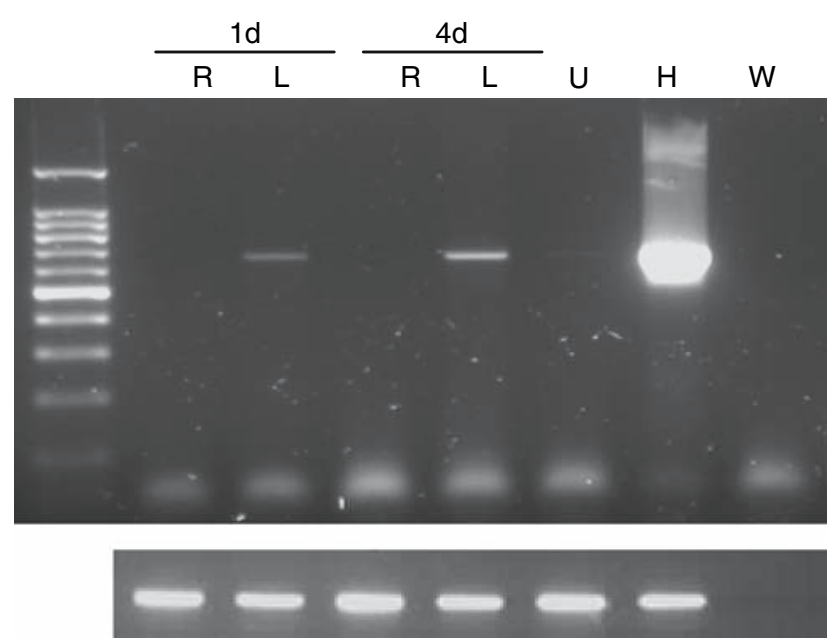

Fig. 7 RT-PCR amplification of human $\beta$-actin gene. $1 d R$ Right TA control muscle 1 day post-vehicle injection. $1 d L$ Left TA muscle 1 day after human fetal skeletal muscle cell injection. $U$ Unwounded control mice, $H$ Human, $W$ Water

was inhibited [62]. The use of fetal cells may bypass these inconveniences. In our study we can still observe human fetal cells and human $\beta$-actin gene expression at 4 days after injection in all the analyzed samples, indicating that cells are still present in a sufficient quantity to detect RNA even with a small amount of injected cells. Herein, we have injected $5 \times 10^{4}$ human fetal muscular cells into mice, when 5 to 100 times more cells are used in other animal studies. Fetal cells are already differentiated as we observe by immunohistochemistry with different fetal cell types. This was also shown in vivo by Sakai et al. in a study wherein three different fetal cell types (cardiomyocytes, smooth muscle and skin fibroblasts) were used to repair a myocardial scar in rats. Histological studies after transplantation showed that the transplanted cells formed a block of tissue composed of their specific cell type in the myocardial scar [63]. Altogether, fetal skeletal muscle cells show qualities required for the establishment of a cell bank to be used for cell therapy. Fetal cells have a higher potential of division before senescence because of the longer telomeres in comparison to adult cells [64]. The rapid growth of the cells facilitates the creation of an important cell bank starting from one donor as it was done for fetal skin cells [55] (Fig. 8). With one organ donation of $1 \mathrm{~cm}^{3}$, we would be able to generate more than $1.5 \times 10^{12}$ cells at passage 4 , and therefore we would have the ability to make more than 28,000 injections with $7 \times 10^{7}$ cells as it was used in the clinics for human Duchenne Muscular Dystrophic patients [65, 66]. For each organ donation, the mother donors are tested for infectious diseases (status of the donor for HIV, HBV and HCV) at the time of tissue donation and again 3 months later to assure negative sero-conversion [47]. Careful selection of a donor and an extensive screening to avoid transmissible viral, fungal or bacterial disease provide a safe and secure utilization of fetal cells for therapeutic usage.
Fig. 8 With one organ donation of $1-2 \mathrm{~cm}^{3}$, it is possible to establish a fetal muscle cell bank that is potentially able to produce more than $1.5 \times 10^{12}$ cells for cellular therapy and tissue engineering

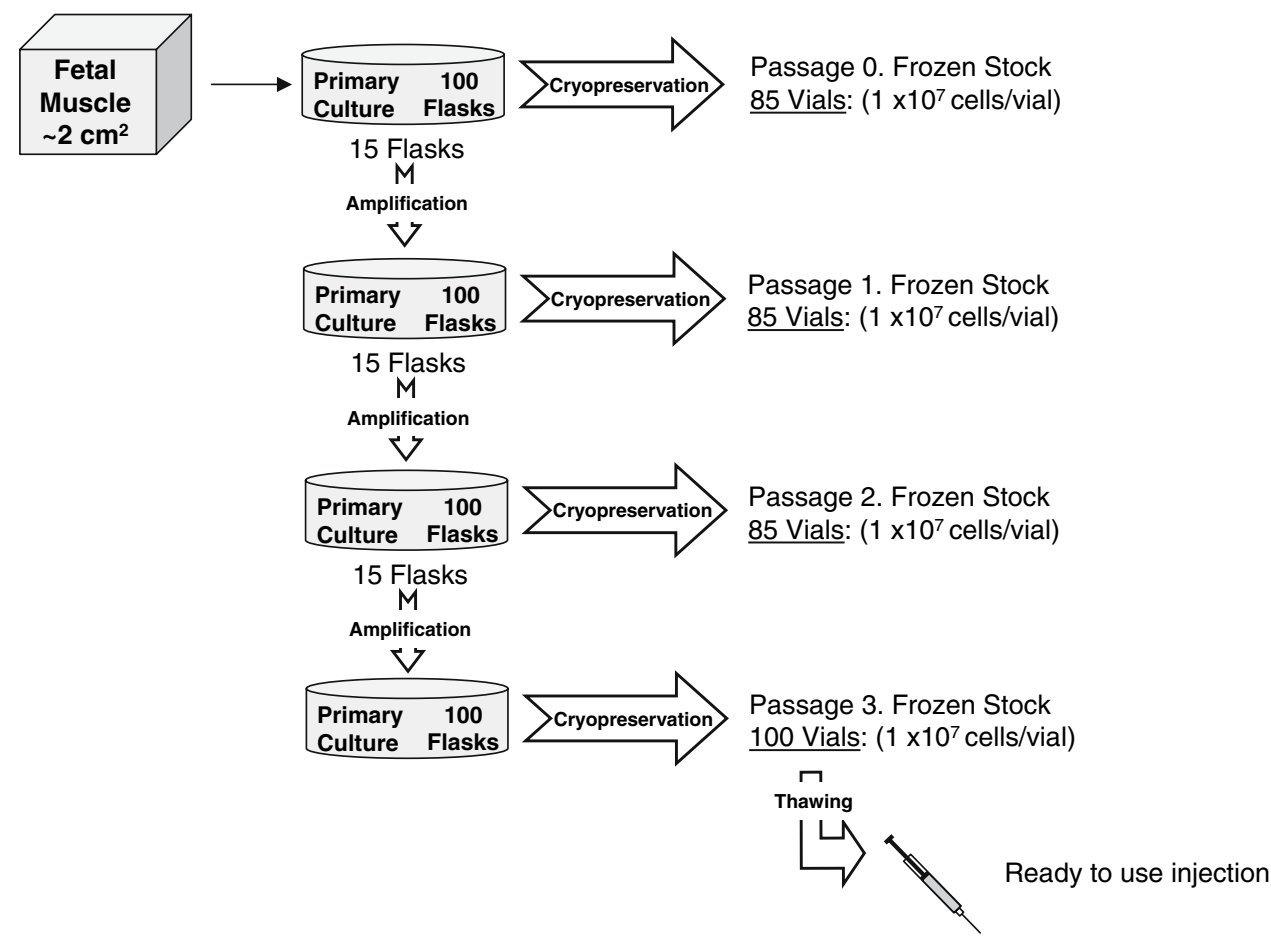


Acknowledgment We wish to thank the Dr. med. h.c. Erwin Braun Foundation for financing, in part, this study. We would thank A. Giraudeau-Christinat and O. Burri for their technical assistance.

\section{References}

1. Partridge T (2002) Myoblast transplantation. Neuromuscul Disord 12(Suppl 1):S3-S6

2. Skuk D, Tremblay JP (2000) Progress in myoblast transplantation: a potential treatment of dystrophies. Microsc Res Tech 48:213-222

3. Skuk D, Vilquin JT, Tremblay JP (2002) Experimental and therapeutic approaches to muscular dystrophies. Curr Opin Neurol 15:563-569

4. Skuk D, Tremblay JP (2003) Myoblast transplantation: the current status of a potential therapeutic tool for myopathies. J Muscle Res Cell Motil 24:285-300

5. Menasche P (2005) Skeletal myoblast for cell therapy. Coron Artery Dis 16:105-110

6. Huard J, Li Y, Fu FH (2002) Muscle injuries and repair: current trends in research. J Bone Joint Surg Am 84-A:822-832

7. Partridge T (2002) Myoblast transplantation. Neuromuscul Disord 12(Suppl 1):S3-S6

8. Partridge TA, Grounds M, Sloper JC (1978) Evidence of fusion between host and donor myoblasts in skeletal muscle grafts. Nature 273:306-308

9. Menasche P (2005) Skeletal myoblast for cell therapy. Coron Artery Dis 16:105-110

10. Partridge TA, Grounds M, Sloper JC (1978) Evidence of fusion between host and donor myoblasts in skeletal muscle grafts. Nature 273:306-308

11. Skuk D, Roy B, Goulet M, Tremblay JP (1999) Successful myoblast transplantation in primates depends on appropriate cell delivery and induction of regeneration in the host muscle. Exp Neurol 155:22-30

12. Partridge T (2002) Myoblast transplantation. Neuromuscul Disord 12(Suppl 1):S3-S6

13. Skuk D, Tremblay JP (2000) Progress in myoblast transplantation: a potential treatment of dystrophies. Microsc Res Tech 48:213-222

14. Partridge T (2002) Myoblast transplantation. Neuromuscul Disord 12(Suppl 1):S3-S6

15. Smythe GM, Hodgetts SI, Grounds MD (2000) Immunobiology and the future of myoblast transfer therapy. Mol Ther 1:304-313

16. Beauchamp JR, Pagel CN, Partridge TA (1997) A dual-marker system for quantitative studies of myoblast transplantation in the mouse. Transplantation 63:1794-1797

17. Beauchamp JR, Morgan JE, Pagel CN, Partridge TA (1999) Dynamics of myoblast transplantation reveal a discrete minority of precursors with stem cell-like properties as the myogenic source. J Cell Biol 144:1113-1122

18. Fan Y, Maley M, Beilharz M, Grounds M (1996) Rapid death of injected myoblasts in myoblast transfer therapy. Muscle Nerve 19:853-860

19. Hodgetts SI, Beilharz MW, Scalzo AA, Grounds MD (2000) Why do cultured transplanted myoblasts die in vivo? DNA quantification shows enhanced survival of donor male myoblasts in host mice depleted of CD4+ and CD8+ cells or Nk1.1+ cells. Cell Transplant 9:489-502

20. Hodgetts SI, Spencer MJ, Grounds MD (2003) A role for natural killer cells in the rapid death of cultured donor myoblasts after transplantation. Transplantation 75:863-871

21. Qu Z, Balkir L, van Deutekom JC, Robbins PD, Pruchnic R, Huard J (1998) Development of approaches to improve cell survival in myoblast transfer therapy. J Cell Biol 142:1257-1267
22. Rando TA, Pavlath GK, Blau HM (1995) The fate of myoblasts following transplantation into mature muscle. Exp Cell Res 220:383-389

23. Sammels LM, Bosio E, Fragall CT, Grounds MD, van Rooijen N, Beilharz MW (2004) Innate inflammatory cells are not responsible for early death of donor myoblasts after myoblast transfer therapy. Transplantation 77:1790-1797

24. Fan Y, Maley M, Beilharz M, Grounds M (1996) Rapid death of injected myoblasts in myoblast transfer therapy. Muscle Nerve 19:853-860

25. Hodgetts SI, Beilharz MW, Scalzo AA, Grounds MD (2000) Why do cultured transplanted myoblasts die in vivo? DNA quantification shows enhanced survival of donor male myoblasts in host mice depleted of CD4+ and CD8+ cells or Nk1.1+ cells. Cell Transplant 9:489-502

26. Tambara K, Sakakibara Y, Sakaguchi G, Lu F, Premaratne GU, Lin X, Nishimura K, Komeda M (2003) Transplanted skeletal myoblasts can fully replace the infarcted myocardium when they survive in the host in large numbers. Circulation 108(Suppl 1):II259-II263

27. Qu Z, Balkir L, van Deutekom JC, Robbins PD, Pruchnic R, Huard J (1998) Development of approaches to improve cell survival in myoblast transfer therapy. J Cell Biol 142:12571267

28. Pavlath GK, Rando TA, Blau HM (1994) Transient immunosuppressive treatment leads to long-term retention of allogeneic myoblasts in hybrid myofibers. J Cell Biol 127:1923-1932

29. Guerette B, Skuk D, Celestin F, Huard C, Tardif F, Asselin I, Roy B, Goulet M, Roy R, Entman M, Tremblay JP (1997) Prevention by anti-LFA- 1 of acute myoblast death following transplantation. J Immunol 159:2522-2531

30. Dellavalle A, Sampaolesi M, Tonlorenzi R, Tagliafico E, Sacchetti B, Perani L, Innocenzi A, Galvez BG, Messina G, Morosetti R, Li S, Belicchi M, Peretti G, Chamberlain JS, Wright WE, Torrente Y, Ferrari S, Bianco P, Cossu G (2007) Pericytes of human skeletal muscle are myogenic precursors distinct from satellite cells. Nat Cell Biol 9:255-267

31. Maurel A, Azarnoush K, Sabbah L, Vignier N, Le Lorc'h M, Mandet C, Bissery A, Garcin I, Carrion C, Fiszman M, Bruneval P, Hagege A, Carpentier A, Vilquin JT, Menasche P (2005) Can cold or heat shock improve skeletal myoblast engraftment in infarcted myocardium? Transplantation 80:660-665

32. Qu Z, Balkir L, van Deutekom JC, Robbins PD, Pruchnic R, Huard J (1998) Development of approaches to improve cell survival in myoblast transfer therapy. J Cell Biol 142:1257-1267

33. Jankowski RJ, Haluszczak C, Trucco M, Huard J (2001) Flow cytometric characterization of myogenic cell populations obtained via the preplate technique: potential for rapid isolation of muscle-derived stem cells. Hum Gene Ther 12:619-628

34. Huard J, Verreault S, Roy R, Tremblay M, Tremblay JP (1994) High efficiency of muscle regeneration after human myoblast clone transplantation in SCID mice. J Clin Invest 93:586-599

35. Torrente Y, Tremblay JP, Pisati F, Belicchi M, Rossi B, Sironi M, Fortunato F, El Fahime M, D'Angelo MG, Caron NJ, Constantin G, Paulin D, Scarlato G, Bresolin N (2001) Intraarterial injection of muscle-derived CD34(+)Sca-1(+) stem cells restores dystrophin in mdx mice. J Cell Biol 152:335-348

36. Vats A, Bielby RC, Tolley NS, Nerem R, Polak JM (2005) Stem cells. Lancet 366:592-602

37. Deasy BM, Jankowski RJ, Huard J (2001) Muscle-derived stem cells: characterization and potential for cell-mediated therapy. Blood Cells Mol Dis 27:924-933

38. Orlic D, Kajstura J, Chimenti S, Jakoniuk I, Anderson SM, Li B, Pickel J, McKay R, Nadal-Ginard B, Bodine DM, Leri A, Anversa P (2001) Bone marrow cells regenerate infarcted myocardium. Nature 410:701-705 
39. De Coppi P, Bartsch G Jr, Siddiqui MM, Xu T, Santos CC, Perin L., Mostoslavsky G, Serre AC, Snyder EY, Yoo JJ, Furth ME, Soker S, Atala A (2007) Isolation of amniotic stem cell lines with potential for therapy. Nat Biotechnol 25:100-106

40. Gang EJ, Jeong JA, Hong SH, Hwang SH, Kim SW, Yang IH, Ahn C, Han H,Kim H (2004) Skeletal myogenic differentiation of mesenchymal stem cells isolated from human umbilical cord blood. Stem Cells 22:617-624

41. De Coppi P, Bartsch G Jr, Siddiqui MM, Xu T, Santos CC, Perin L., Mostoslavsky G, Serre AC, Snyder EY, Yoo JJ, Furth ME, Soker S, Atala A (2007) Isolation of amniotic stem cell lines with potential for therapy. Nat Biotechnol 25:100-106

42. Barry FP, Murphy JM (2004) Mesenchymal stem cells: clinical applications and biological characterization. Int J Biochem Cell Biol 36:568-584

43. Bullard KM, Longaker MT, Lorenz HP (2003) Fetal wound healing: current biology. World J Surg 27:54-61

44. Bhattacharya N (2004) Fetal cell/tissue therapy in adult disease: a new horizon in regenerative medicine. Clin Exp Obstet Gynecol 31:167-173

45. Hohlfeld J, De Buys Roessingh AS, Hirt-Burri N, Chaubert P, Gerber S, Scaletta C, Hohlfeld P, Applegate LA (2005) Tissue engineered fetal skin constructs for paediatric burns. The Lancet 366:840-842

46. Montjovent MO, Burri N, Mark S, Federici E, Scaletta C, Zambelli PY, Hohlfeld P, Leyvraz PF, Applegate LA, Pioletti DP (2004) Fetal bone cells for tissue engineering. Bone 35:13231333

47. De Buys Roessingh AS, Hohlfeld J, Scaletta C, Hirt-Burri N, Gerber S, Hohlfeld P, Gebbers JO,Applegate LA (2006) Development, characterization, and use of a fetal skin cell bank for tissue engineering in wound healing. Cell Transplant 15:823-834

48. Crombleholme TM, Langer JC, Harrison MR, Zanjani ED (1991) Transplantation of fetal cells. Am J Obstet Gynecol 164:218-230

49. Gabbianelli M, Boccoli G, Petti S, Cianetti L, La Valle R, Ferbus D, Mastroberardino G, Testa U, Peschle C (1987) Expression and in-vitro modulation of HLA antigens in ontogenic development of human hemopoietic system. Ann N Y Acad Sci 511:138-147

50. Clarkson ED (2001) Fetal tissue transplantation for patients with Parkinson's disease: a database of published clinical results. Drugs Aging 18:773-785

51. Bachoud-Levi AC, Gaura V, Brugieres P, Lefaucheur JP, Boisse MF, Maison P, Baudic S, Ribeiro MJ, Bourdet C, Remy P, Cesaro P, Hantraye P, Peschanski M (2006) Effect of fetal neural transplants in patients with Huntington's disease 6 years after surgery: a long-term follow-up study. Lancet Neurol 5:303-309

52. Peterson CM, Jovanovic-Peterson L, Formby B, Gondos B, Monda LM, Walker L, Rashbaum W, Williams K (1989) Human fetal pancreas transplants. J Diabet Complications 3:27-34

53. Pioletti DP, Montjovent MO, Zambelli PY, Applegate LA (2006) Bone tissue engineering using foetal cell therapy. Swiss Med Wkly 136:557-560
54. Montjovent MO, Burri N, Mark S, Federici E, Scaletta C, Zambelli PY, Hohlfeld P, Leyvraz PF, Applegate LA, Pioletti DP (2004) Fetal bone cells for tissue engineering. Bone 35:13231333

55. Quintin A, Hirt-Burri N, Scaletta C, Schizas C, Pioletti DP, Applegate LA (2007) Consistency of fetal cell banks for research and clinical use. Cell Transplant (in press)

56. Montjovent MO, Burri N, Mark S, Federici E, Scaletta C, Zambelli PY, Hohlfeld P, Leyvraz PF, Applegate LA, Pioletti DP (2004) Fetal bone cells for tissue engineering. Bone 35:13231333

57. Walsh FS, Ritter MA (1981) Surface antigen differentiation during human myogenesis in culture. Nature 289:60-64

58. Schafer R, Knauf U, Zweyer M, Hogemeier O, de Guarrini F, Liu X, Eichhorn HJ, Koch FW, Mundegar RR, Erzen I, Wernig A (2006) Age dependence of the human skeletal muscle stem cell in forming muscle tissue. Artif Organs 30:130-140

59. Schafer R, Knauf U, Zweyer M, Hogemeier O, de Guarrini F, Liu X, Eichhorn HJ, Koch FW, Mundegar RR, Erzen I, Wernig A (2006) Age dependence of the human skeletal muscle stem cell in forming muscle tissue. Artif Organs 30:130-140

60. Hodgetts SI, Beilharz MW, Scalzo AA, Grounds MD (2000) Why do cultured transplanted myoblasts die in vivo? DNA quantification shows enhanced survival of donor male myoblasts in host mice depleted of CD4+ and CD8+ cells or Nk1.1+ cells. Cell Transplant 9:489-502

61. Fan Y, Beilharz MW, Grounds MD (1996) A potential alternative strategy for myoblast transfer therapy: the use of sliced muscle grafts. Cell Transplant 5:421-429

62. Tambara K, Sakakibara Y, Sakaguchi G, Lu F, Premaratne GU, Lin X, Nishimura K, Komeda M (2003) Transplanted skeletal myoblasts can fully replace the infarcted myocardium when they survive in the host in large numbers. Circulation 108(Suppl 1):II259-II263

63. Sakai T, Li RK, Weisel RD, Mickle DA, Jia ZQ, Tomita S, Kim EJ, Yau TM (1999) Fetal cell transplantation: a comparison of three cell types. J Thorac Cardiovasc Surg 118:715-724

64. Decary S, Mouly V, Hamida CB, Sautet A, Barbet JP, ButlerBrowne GS (1997) Replicative potential and telomere length in human skeletal muscle: implications for satellite cell-mediated gene therapy. Hum Gene Ther 8:1429-1438

65. Skuk D, Roy B, Goulet M, Chapdelaine P, Bouchard JP, Roy R, Dugre FJ, Lachance JG, Deschenes L, Helene S, Sylvain M, Tremblay JP (2004) Dystrophin expression in myofibers of Duchenne muscular dystrophy patients following intramuscular injections of normal myogenic cells. Mol Ther 9:475-482

66. Skuk D, Goulet M, Roy B, Piette V, Cote CH, Chapdelaine P, Hogrel JY, Paradis M, Bouchard JP, Sylvain M, Lachance JG, Tremblay JP (2007) First test of a "high-density injection" protocol for myogenic cell transplantation throughout large volumes of muscles in a Duchenne muscular dystrophy patient: eighteen months follow-up. Neuromuscul Disord 17:38-46 